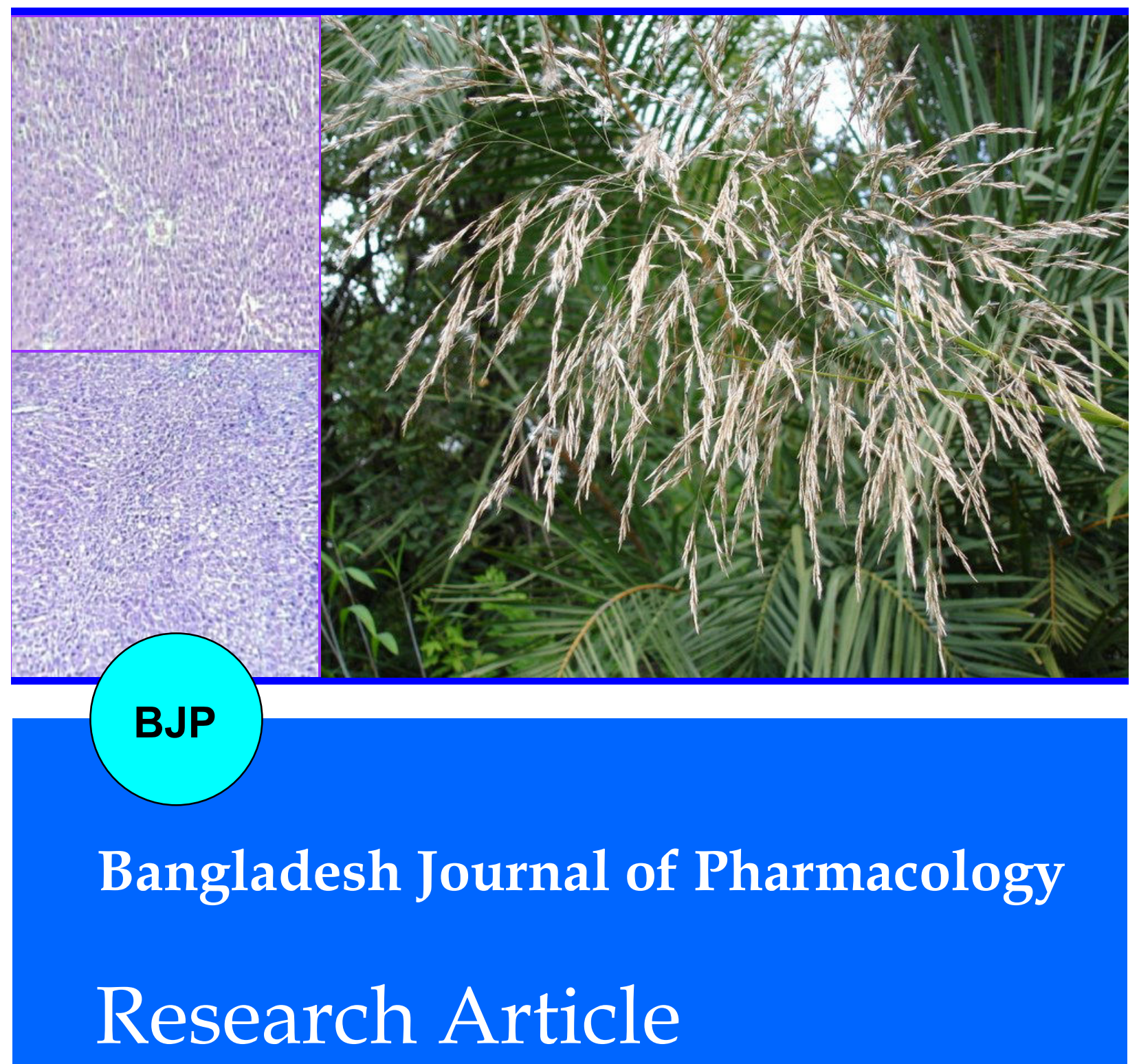

Evaluation of methanolic extract of Phragmites karka on carbon tetrachloride-induced liver fibrosis in rat 


\title{
Evaluation of methanolic extract of Phragmites karka on carbon tetrachloride-induced liver fibrosis in rat
}

\author{
Atta Ur Rehman', Manal Liaquat², Rabia Asghar² and Nawazish-i-Husain Syed3 \\ ${ }^{1}$ Department of Pharmacy, Forman Christian College, Lahore 54600, Pakistan; ${ }^{2}$ Faculty of Pharmacy, The \\ University of Lahore, Lahore, Pakistan; ${ }^{2}$ Department of Pharmacology, Punjab University College of Pharmacy, \\ University of the Punjab, Lahore 54000, Pakistan.
}

\begin{tabular}{|c|c|}
\hline Article Info & \\
\hline Received: & 3 May 2017 \\
\hline Accepted: & 21 July 2017 \\
\hline Available Online: & 30 July 2017 \\
\hline DOI: $10.3329 /$ bjp.v & 2128 \\
\hline $\begin{array}{l}\text { Cite this article: } \\
\text { Rehman AU, Liac } \\
\text { Syed N. Evaluat } \\
\text { extract of Phragmi } \\
\text { tetrachloride-indu } \\
\text { rat. Bangladesh J F } \\
\text { 276-81. }\end{array}$ & $\begin{array}{l}\text { A, Asghar R, } \\
\text { f methanolic } \\
\text { rka on carbon } \\
\text { er fibrosis in } \\
\text { acol. 2017; 12: }\end{array}$ \\
\hline
\end{tabular}

\begin{abstract}
Phragmites karka has been reported for its anti-inflammatory and analgesic activities. Here, extracts of leaf and rhizome of the plant were individually investigated in $\mathrm{CCl}_{4}$-induced hepatofibrosis in male Wistar rats by administering $\mathrm{CCl}_{4}$ intraperitoneally biweekly for 6 weeks. Afterwards the animals were investigated for liver fibrosis at biochemical, molecular and histological levels, and it showed a profound increase $(p<0.001)$ in elevation of serum levels of transaminases, $\gamma$-glutamyl transpeptidase, mRNA expression of a smooth muscle actin, collagen and transforming growth factor beta (TGF $\beta$ ), and extracellular matrix deposition and perilobular necrosis. Both extracts markedly $(p<0.001)$ decreased the elevated levels of these markers. Histopathological investigations also substantiated the above results by exhibiting a decreased in extracellular matrix deposition in post-treatment animals. In conclusion, both extracts had substantially modified the biochemical and molecular markers of liver fibrosis, in addition to histological improvement in architecture of liver.
\end{abstract}

\section{Introduction}

Hepatic fibrosis is a continuous wound healing response to repeated liver injuries which may be caused by viral hepatitis, alcohol abuse and other hepatotoxic agents (Friedrich-Rust et al., 2009; Rehman, 2014). It is initially a critical intermediary step in the progression to liver cirrhosis and latterly hepatocellular carcinoma (Zhou et al., 2014). In hepatic fibrosis, hepatic stellate cells are activated and form an excessive extra-cellular matrix that includes collagens and fibronectins (Tsukada et al., 2006). Accumulation of extracellular matrix proteins forms a dense fibrous scar, thus interrupting normal architecture of liver tissue. It compromises the flow of blood in the liver and causes an oxidative burden on the organ, thus paving the way for regene- ration of parenchymal nodules and ultimately leading to cirrhosis (Ismail and Pinzani, 2009). Furthermore, continuous hepatic stellate cells activation leads to myofibroblast transition via the release of pro-fibrogenic cytokines including transforming growth factor (TGF- $\beta$ ) (Bisselle et al., 1995; Desmouliere et al., 1993; Dooley et al., 2012), platelet-derived growth factor, and connective tissue growth factor (Tsukada et al., 2006). Therefore, it is one important reason that hepatic stellate cells and expressed cytokines e.g., TGF- $\beta$ (Inagaki et al., 2005; Tiggelman et al., 1995 ) is investigated as a therapeutic target for treating liver fibrosis and cirrhosis.

In search of ideal molecules to treat the hepatic injury and hepatofibrosis, scientists are also diverting their 
attention towards the natural remedies (Ahmed et al., 20116; Gonzalez et al 2016; Gu et al., 2013). Phragmites karka belongs to the family Pocaceae, which is wildly distributed in Punjab and Kashmir regions of Pakistan and used as a folk medicine for the treatment of rheumatic pains and other inflammatory conditions. It has been reported to contain chemical entities such as pentosans, lignins, flavonoids, steroids, terpenoids, tannins and alkaloids (Abideen et al., 2015; Sultan et al., 2017). Its leaf exhibits the highest polyphenol contents, which may attribute to its reported anti-oxidant activity (Abideen et al., 2015). Its rhizome and root are known for the antiemetic and diaphoretic action, and are also used for the treatment of diabetes (Oyen 2011). The leaf exhibits analgesic, antidepressant and antinociceptive activities (Sultan et al., 2017).

Keeping in view, its folklore use as a medicinal plant in various inflammatory ailments, this study was thus designed to explore its role in an animal model of hepatofibrosis.

\section{Materials and Methods}

\section{Plant Material}

The plant was collected from the Lahore region and identified by a taxonomist of the Department of Botany, Government College University, Lahore, Pakistan. The specimens of the leaf and rhizome of the plant were deposited in the herbarium and voucher number GC Herb. Bot. 2916 was issued.

\section{Preparation of the Extract}

The leaf and rhizome of P. karka were thoroughly washed with water and dried in shade before grinding. Dried powdered leaf (500 g) and rhizome (300 g) of $P$. karka were separately macerated in methanol $(2 \mathrm{~L})$ for 8 days at an ambient room temperature with occasional shaking and stirring. The macerate was removed and the cake was macerated again for two more times. The macerates were filtered through the muslin cloth followed by filtration through Whatman filter paper No. 8. The extract was concentrated in a rotary evaporator (company) at $50^{\circ} \mathrm{C}$ and $90 \mathrm{rpm}$. The viscous mass obtained was dried to semisolid consistency and stored at $4^{\circ} \mathrm{C}$.

\section{Animals}

Male Wistar rats weighing 150-250 g were given standard laboratory food, water ad libitum and maintained at the natural day-night cycle. The animals were acclimatized to the lab conditions for one week before starting the experiment.

\section{Chemicals}

Methanol and $\mathrm{CCl}_{4}$ were purchased from the SigmaAldrich (UK). Corn oil was purchased from the local manufacturer. Serum aminotransferases and $\mathrm{Y}^{-}$ glutamyl transpeptidase were performed using the kit (LABTEST, TRON, France).

\section{Induction of Fibrosis and Treatment Plans}

Liver fibrosis was induced in rats using previous protocol (Nakamura et al., 1999) with minor modifications. Rats were intraperitoneally (IP) injected with $\mathrm{CCl}_{4}$ dissolved in corn oil biweekly for 6 weeks. In the first week $0.5 \mu \mathrm{L} \mathrm{CCl} C_{4}$ /gram of body weight (g); in the second week $0.75 \mu \mathrm{L} \mathrm{CCl}_{4} / \mathrm{g}$ and for the rest of 4 weeks $1 \mu \mathrm{L} \mathrm{CCl} / \mathrm{g})$. The control animals were administered (IP) corn oil only. The investigational treatment was started from the 3rd week onwards with the leaf and rhizome extract at indicated doses.

\section{Experimental Groups}

Male Wistar rats were randomly assigned to 6 groups ( $n=5$ in each group). Group 1 served as control group and administered (IP) with corn oil. Group 2 and 3 were daily administered with the leaf extract $(500 \mathrm{mg} /$ $\mathrm{kg}$ ) and rhizome extract $(500 \mathrm{mg} / \mathrm{kg}$ ) respectively, via oral gavage tube. Group 4 was fibrosis positive group and the rats were administered $\mathrm{CCl}_{4}$ (as mentioned above). Group 5 and 6 served as treatment groups. They were daily administered with leaf extract (500 $\mathrm{mg} / \mathrm{kg}$ ) and rhizome extract $(500 \mathrm{mg} / \mathrm{kg}$ ) respectively, in addition to $\mathrm{CCl}_{4}$ (IP). All the doses were administered in absence of anesthesia.

\section{Collection of Serum and Liver Samples}

Rats were anatomized under anesthesia one day after the last dose was given. Blood was collected by means of cardiac puncture. The serum was collected by centrifugation at 4,000 rpm for 4-5 min. Tissue samples of liver were stored in $10 \%$ formaldehyde for fixation. Liver tissues were also preserved at $-20^{\circ} \mathrm{C}$ for real time PCR.

\section{Liver Function Tests}

Serum aminotransferases and $\gamma$-glutamyl transpeptidase levels were determined using the manufactures' protocol.

\section{Histopathological Evaluation}

Liver tissues were sliced ( $5 \mu \mathrm{m}$ thickness) using a rotary microtome and stained with hematoxylin and eosin $(\mathrm{H}$ \& E) stain by adopting standard lab procedure.

\section{mRNA Expression Analysis}

Total RNA extraction, complementary DNA (cDNA) and real-time PCR were carried out using the kits from WizBio Solution (Korea). To determine the mRNA levels of TGB- $\beta$, a-SMA and collagen following primers sequences were used:

18S: F5'CGG CTA CCA CAT CCA AGG A 3', R5'CCA ATT ACA GGG CCT CGA AA3'; a-SMA: F 5'GCC AGT 
CGC CAT CAG GAA C3', R5'CAC ACC AGA GCT GTG CTG TCT T3'; Collagen: F 5'TGG TGA ACG TGG TGT ACA AGG T3', R 5'CAG TAT CAC CCT TGG CAC CAT3'; TGF $\beta$ : F 5'GGG CTA CCA TGC CAA CTT CTG 3', R 5'GAG GGC AAG GAC CTT GCT GTA3'.

\section{Statistical Analysis}

All data are expressed as the mean \pm standard deviation (SD). Statistically significant differences between the groups were analyzed by one-way analysis of variance (ANOVA) followed by Bonferonni's descriptive test. Differences with $\mathrm{p}<0.05$ were considered statistically significant.

\section{Results}

\section{Effects on serum aminotransferase and $r$-glutamyl} transpeptidase

Figure 1 shows the effect of $P$. karka extract on serum aminotransferase and $\gamma$-glutamyl transpeptidase. Initially, the corn oil treated control group was compared with groups of animals treated with leaf extract or rhizome extract alone where the data showed no significant increase in serum levels of aminotransferase and $\gamma$-glutamyl transpeptidase. $\mathrm{CCl}_{4}$-treated group showed a significant $(\mathrm{p}<0.001)$ increase in the serum levels of aminotransferase and $\gamma$-glutamyl transpeptidase when compared with the control. Thereafter, $\mathrm{CCl}_{4-}$ treated control group was compared with group which were treated with $\mathrm{CCl}_{4}$ and leaf/rhizome extract. The data clearly indicated a significant $(\mathrm{p}<0.001)$ decline in the serum levels of aminotransferase and $\gamma$-glutamyl transpeptidase compared to $\mathrm{CCl}_{4}$-treated group.

\section{mRNA expression evaluation of liver fibrosis markers}

Figure 2 shows the mRNA expression evaluation of aSMA, TGF $\beta$ and collagen. The data showed that there was a 1-fold increase in mRNA expression of a-SMA in $\mathrm{CCl}_{4}$-treated group as compared to the control group (Figure 2A). Treatment with leaf extract alone lowered the levels of a-SMA by half as compared to the control (vehicle treated) group, whereas rhizome extract did not show any effect on a-SMA mRNA expression. Interestingly, both extracts exhibited a significant $(\mathrm{p}<0.001)$ down-regulation of mRNA (compare $\mathrm{CCl}_{4}{ }^{-}$ treated and leaf or rhizome extract group with the $\mathrm{CCl}_{4}{ }^{-}$ treated group. Moreover, leaf extract seemed to be more effective in terms of mRNA expression of a-SMA when compared with rhizome extract-treated group.

Figure 2B shows mRNA expression of TGF $\beta$. The data shows that there was a 2-fold increase in mRNA expression of TGF $\beta$ in $\mathrm{CCl}_{4}$-treated group as compared to the control group. Leaf extract did not show any

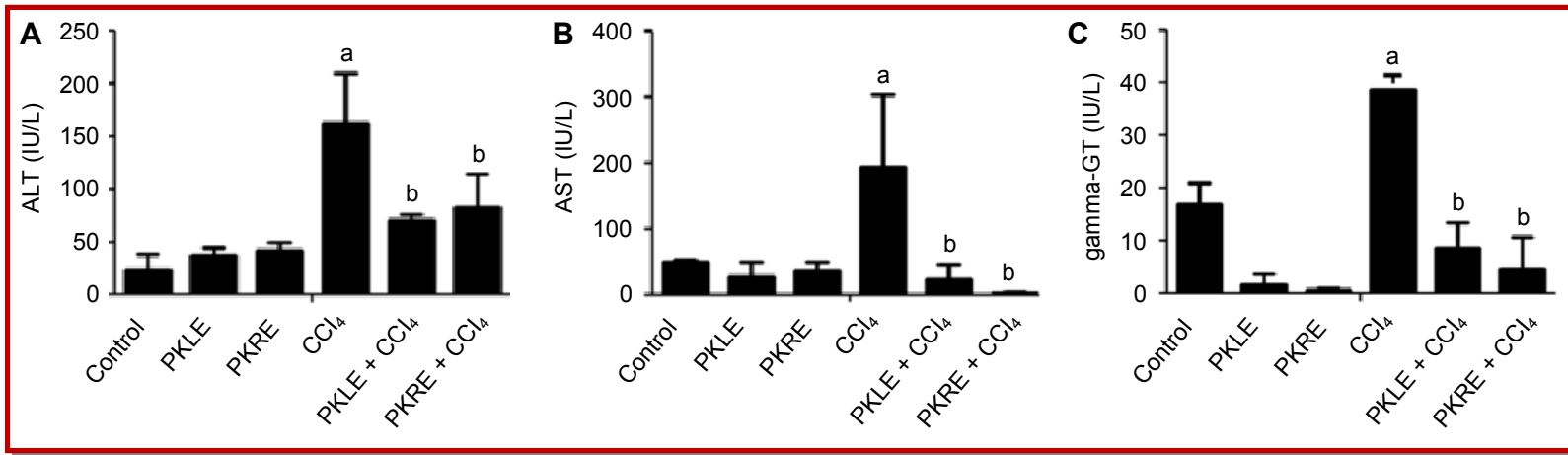

Figure 1: ALT (A), AST (B) and GGT (C) values of different groups; Data is represented as Mean \pm SD; "a" Shows significant difference Vs Control Group; "b" Shows significant difference Vs $\mathrm{CCl}_{4}$ Group
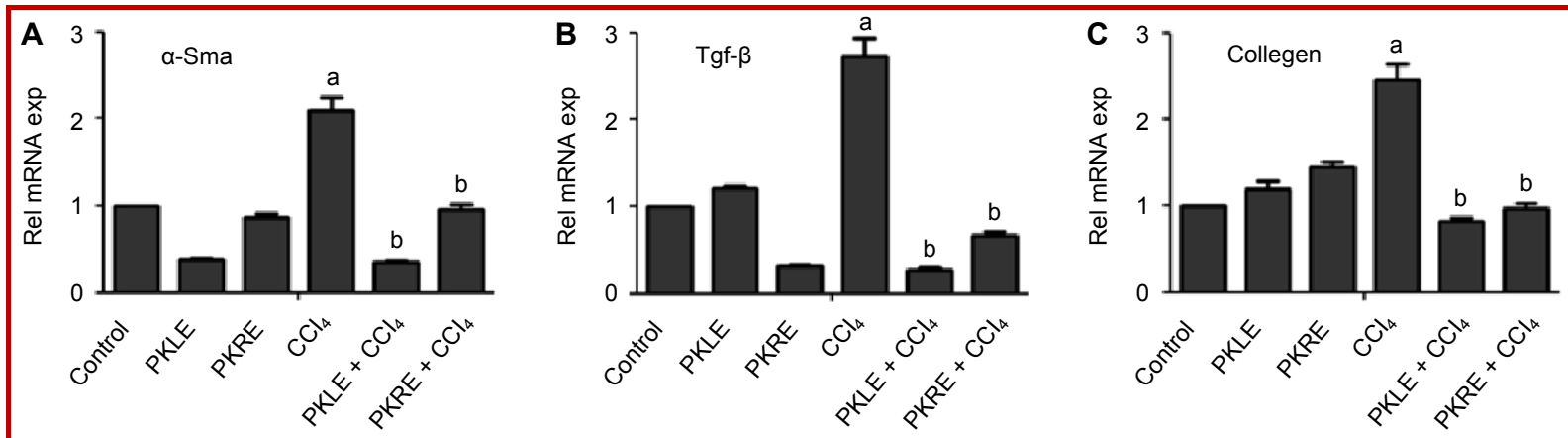

Figure 2: mRNA expression values of $\alpha$ - Smooth muscle actin (A), transforming growth factor- $\beta$ (B) and collagen (C); Data is represented as Mean \pm SD; "a" Shows significant difference Vs Control Group. "b" Shows Significant difference Vs $\mathrm{CCl}_{4} \mathrm{Group}$ 


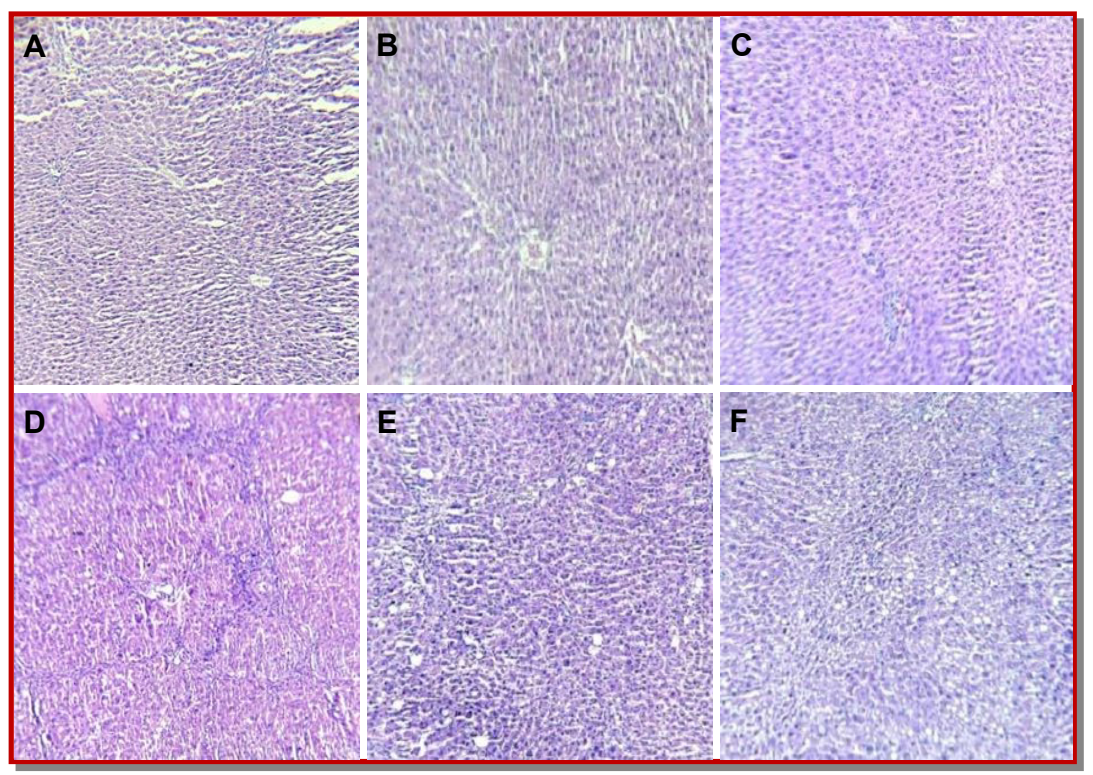

Figure 3: Microscopic evaluation of $\mathrm{H} \& \mathrm{E}$ stained liver tissue. Representative of $\mathrm{n}=5$ from each group. A: Corn oil treatment, B: Corn oil + leaf extract $(500 \mathrm{mg} / \mathrm{kg})$, C: Corn oil + rhizome extract $(500 \mathrm{mg} / \mathrm{kg})$ D; CCL 4 treated, E: CCL 4 + leaf extract $500 \mathrm{mg} / \mathrm{kg}$, F: Corn oil+ rhizome extract $500 \mathrm{mg} / \mathrm{kg}$

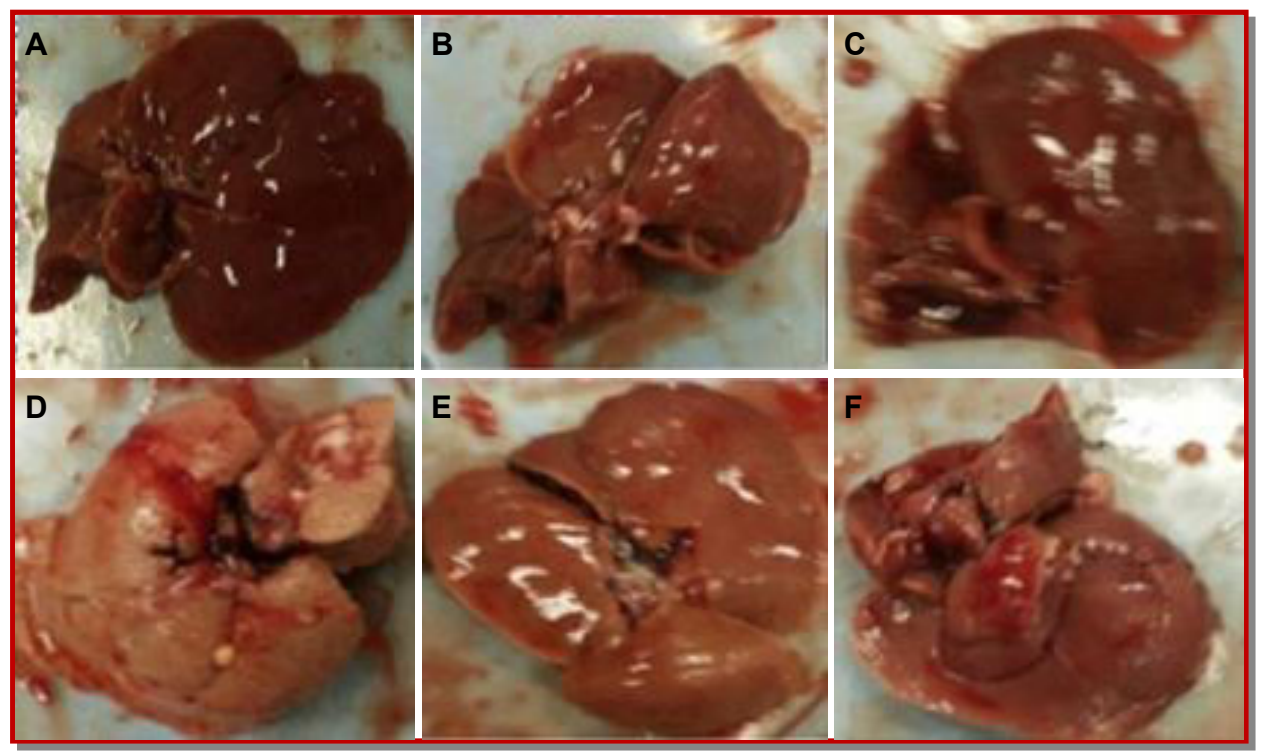

Figure 4: Gross appearance of livers. Excised livers from the treated animals after dissection and photographed. Representative of $\mathrm{n}=5$ from each group. A: Corn oil treatment, B: Corn oil + leaf extract $(500 \mathrm{mg} / \mathrm{kg})$, C: Corn oil + rhizome extract (500 mg/kg) D: $\mathrm{CCL}_{4}$ treated, E: $\mathrm{CCL}_{4}+$ leaf extract $500 \mathrm{mg} / \mathrm{kg}$, F: Corn oil+ rhizome extract $500 \mathrm{mg} / \mathrm{kg}$

change in the mRNA levels of TGF $\beta$ as compared to the control group. However, rhizome extract profoundly reduced the mRNA expression levels of TGF $\beta$ compared to control. Both extracts of P. karka exhibited a significant $(\mathrm{p}<0.001)$ down-regulation of mRNA levels of TGF $\beta$ (compare $\mathrm{CCl}_{4}$-treated and leaf or rhizome extract group with the $\mathrm{CCl}_{4}$-treated group.

There was more than 1-fold increase in mRNA expression of collagen in $\mathrm{CCl}_{4}$-treated group as compared to the control group (Figure 2C). Both extracts did not modify the mRNA expression levels of the collagen as compared to the control group. However, leaf and rhizome extracts managed to reduce the $\mathrm{CCl}_{4}$-induced mRNA expression levels of collagen significantly $(\mathrm{p}<0.001)$ (compare $\mathrm{CCl}_{4}$-treated and leaf or rhizome extract group with the $\mathrm{CCl}_{4}$-treated group).

\section{Histopathological and gross view findings from the} liver tissue

Figure 3 shows microscopic view of liver tissue from various experimental groups, Figure $3 \mathrm{~A}, \mathrm{~B}$ and $\mathrm{C}$ show normal arrangement of hepatocytes, while liver of animal treated with $\mathrm{CCl}_{4}$ showed disarrangement of 
hepatocytes, fatty degeneration and massive number of inflammatory cells in the liver tissue (Figure 3D). In comparison liver of animal treated with leaf extract (Figure 3) and rhizome extract (Figure 3F) in $\mathrm{CCl}_{4}$ intoxicated rats show improved features and lesser degree of hepatocyte disarrangement.

Figure 4 shows the gross overview of livers from different experimental groups respectively and complements the results found in Figure 3. Liver from the control animal (Figure 4A) had smooth shiny surface while treatment with $\mathrm{CCl}_{4}$ (as shown in Figure 4D) led the color changed to whitish with decreased amount of blood, nodular appearance and felt very hard to touch as compared to the liver of control groups (Figure 4A). Figure 4E and F show gross appearance of liver of animal treated with leaf and rhizome extract in $\mathrm{CCl}_{4}$ intoxicated rats which showed lesser degree of nodulation as compared to $\mathrm{CCl}_{4}$ intoxicated rat livers.

\section{Discussion}

The results suggest that $P$. karka leaf and rhizome extracts prevent the experimentally induced liver damage and fibrosis by repressing the mRNA expression levels of fibrosis related genes, improving liver architecture and serum markers of liver damage.

This study used chronic model of liver injury to induced liver fibrosis and cirrhosis (Liedtke et al., 2013). In line with previously reported study (Gou et al., 2013; Kew C, 2000), administration of $\mathrm{CCl}_{4}$ led to hepatocyte destruction and increased levels of ALT, AST, and GGT in the serum of rats, which were reversed by treatment with the leaf and rhizome extract. Also, in line with earlier observation carried out by (Mohammed et al., 2016), $\mathrm{CCl}_{4}$ treatment caused profound induction of the mRNA levels of TGF $\beta$, a-SMA and collagen genes which were repressed on treatment with both extracts. It suggests that the chemical constituent (s) of both extracts may likely have some regulatory role on the expression of mRNA of the studied genes. However, it is still to be determined whether antifibrotic effects are due to the direct inhibitory action on hepatic stellate cells activation or by anti-oxidant potentials possessed by the extracts (Nimse et al., 2015; Van acker et al., 1996); since oxidative stress play crucial role in hepatic injury and hepatic stellate cell proliferation. (Dunning et al., 2013)

Another possible mechanism of action can be related to the presence of steroidal constituents present in $P$. karka. Sultan et al., has reported the presence of steroidal moieties in P. karka (Sultan et al., 2017), which suggests its diversified effects on prostaglandin synthesis pathway. Prostaglandins and leukotrienes are implicated in pathophysiology of liver injury and are synthesised via acrachidonic acid pathway (Fireman et al., 2004; Nanji et al., 1993; Op den Winkel et al., 2013). A sophisticated balance between leukotrienes and prostaglandins is crucial for physiological performance (Moore and Peters-Golden, 2006). Since, the synthesis of prostaglandins and leukotrienes can be inhibited by steroidal and non-steroidal anti-inflammatory agents and, P. karka is known for its steroidal content and analgesic action. Therefore, the steroidal constituents may involve in antifibrotic actions observed in this study. However, further studies required to elucidate these mechanisms. In general, our data is in agreement with the existing studies which have also shown hepatoprotective and antifibrotic actions in the liver (Mohammed et al., 2016).

\section{Conclusion}

$\mathrm{CCl}_{4}$-induced biochemical (ALT, AST, GGT) and molecular (TGF $\beta$, a-SMA and collagen) markers of liver damage and fibrosis have been profoundly modified toward normalcy in the hepatofibrotic rats. In addition, the histopathological markers analysis have also supported the above biochemical and molecular studies.

\section{Ethical Issue}

The experiments were approved by the Animal Research Ethics Committee of The University of Lahore, Pakistan. Care and handling of animals followed the internationally accepted procedures according to the Institute for Laboratory Animal Research's Guide for the Care and Use of Laboratory Animals.

\section{Conflict of Interest}

All authors have completed the ICMJE uniform disclosure form and declare no support from any organization for the submitted work.

\section{Acknowledgement}

Acknowledgement is due to the faculty of pharmacy administration, University of Lahore for supporting this research, Mr. Shoaib, Mr. Javed Tahir and Dr. M.H. Qazi from Center for Research in Molecular Medicine, The University of Lahore. Authors also thankful to Dr. Azmat Rasheed from Department of Botany, Government College University, Lahore, Pakistan for plant identification.

\section{References}

Abideen Z, Qasim M, Rasheed A, Adnan MY, Gul B, Khan MA. Antioxidant activity and polyphenolic content of Phragmites karka under saline conditions. Pakistan J Bot. 2015; 47: 813-18. 
Ahmed M, Khan AF, Kamran SH, Rehman AU. Amelioration of oral contraceptives induced hepatotoxicity by methanolic extract of turmeric (Curcuma longa Linn.). IJBPAS. 2016; 5: 104-17.

Bissell DM, Wang SS, Jarnagin WR, Roll FJ. Cell-specific expression of transforming growth factor-beta in rat liver: Evidence for autocrine regulation of hepatocyte proliferation. J Clin Invest. 1995; 96: 447-55.

Desmouliere A, Geinoz A, Gabbiani F, Gabbiani G. Transforming growth factor-beta 1 induces alpha-smooth muscle actin expression in granulation tissue myofibroblasts and in quiescent and growing cultured fibroblasts. J Cell Biol. 1993; 122: 103-11.

Dooley S, ten Dijke P. TGF- $\beta$ in progression of liver disease. Cell Tissue Res. 2012; 347: 245-56.

Dunning S, Ur Rehman A, Tiebosch MH, Hannivoort RA, Haijer FW, Woudenberg J, van den Heuvel FA, BuistHoman M, Faber KN, Moshage H. Glutathione and antioxidant enzymes serve complementary roles in protecting activated hepatic stellate cells against hydrogen peroxideinduced cell death. Biochim Biophys Acta. 2013; 1832: 202734 .

Fireman E, Schwartz Y, Mann A, Greif J. Effect of montelukast, a cysteinyl receptor antagonist, on myofibroblasts in interstitial lung disease. J Clin Immunol. 2004; 24: 418-25.

Friedrich-Rust M, Wunder K, Kriener S, Sotoudeh F, Richter S, Bojunga J, Herrmann E, Poynard T, Dietrich CF, Vermehren J. Liver fibrosis in viral hepatitis: Noninvasive assessment with acoustic radiation force impulse imaging versus transient elastography 1. Radiology 2009; 252: 595-604.

González-Ponce HA, Martínez-Saldaña MC, Rincón-Sánchez AR, Sumaya-Martínez MT, Buist-Homan M, Faber KN, Moshage H, Jaramillo-Juárez F. Hepatoprotective effect of Opuntia robusta and Opuntia streptacantha fruits against acetaminophen-induced acute liver damage. Nutrients 2016; 8: 607 .

Gou X, Tao Q, Feng Q, Peng J, Zhao Y, Dai J, Wang W, Zhang $\mathrm{Y}, \mathrm{Hu} \mathrm{Y}$, Liu P. Urine metabolic profile changes of CCl4liver fibrosis in rats and intervention effects of Yi Guan Jian decoction using metabonomic approach. BMC Complement Altern Med. 2013; 13: 123.

Gu J, Gui Y, Chen L, Yuan G, Lu HZ, Xu X. Use of natural products as chemical library for drug discovery and network pharmacology. PLoS One. 2013; 8: e62839.

Inagaki $Y$, Kushida M, Higashi $K$, Itoh J, Higashiyama R, Hong YY, Kawada N, Namikawa K, Kiyama H, Bou-Gharios G, Watanabe T, Okazaki I, Ikeda K. Cell type-specific intervention of transforming growth factor beta/Smad signaling suppresses collagen gene expression and hepatic fibrosis in mice. Gastroenterology 2005; 129: 259-68.

Ismail MH, Pinzani M. Reversal of liver fibrosis. Saudi J Gastroenterol. 2009; 15: 72-79.
Kew MC. Serum aminotransferase concentration as evidence of hepatocellular damage. Lancet 2000; 355: 591-92.

Liedtke C, Luedde T, Sauerbruch T, Scholten D, Streetz K, Tacke F, Tolba R, Trautwein C, Trebicka J, Weiskirchen R. Experimental liver fibrosis research: Update on animal models, legal issues and translational aspects. Fibrogenesis Tissue Repair. 2013; 6: 19.

Mohammed A, Abd Al Haleem EN, El-Bakly WM, ElDemerdash E. Deferoxamine alleviates liver fibrosis induced by $\mathrm{CCl} 4$ in rats. Clin Exper Pharmacol Physiol. 2016; 43: 760-68.

Moore BB, Peters-Golden M. Opposing roles of leukotrienes and prostaglandins in fibrotic lung disease. Exp Rev Clin Immunol. 2006; 2: 87-100.

Nakamura T, Akiyoshi H, Saito I, Sato K. Adenovirusmediated gene expression in the septal cells of cirrhotic rat livers. J Hepatol. 1999; 30: 101-06.

Nanji AA, Khettry U, Sadrzadeh SM, Yamanaka T. Severity of liver injury in experimental alcoholic liver disease: Correlation with plasma endotoxin, prostaglandin E2, leukotriene B4, and thromboxane B2. Am J Pathol. 1993; 142: 367-73.

Nimse SB, Pal D. Free radicals, natural antioxidants, and their reaction mechanisms. RSC Adv. 2015; 5: 27986-06.

Op den Winkel M, Gmelin L, Schewe J, Leistner N, Bilzer M, Goke B, Gerbes AL, Steib CJ. Role of cysteinyl-leukotrienes for portal pressure regulation and liver damage in cholestatic rat livers. Lab Invest. 2013; 93: 1288-94.

Oyen LPA. Phragmites karka (Retz.) Trin. ex Steud. Pages Phragmites karka (PROTA). Wageningen, Netherlands: PROTA (Plant Resources of Tropical Africa). 2011.

Rehman AU. ABC transporters as therapeutic targets for liver fibrosis. University of Groningen, Wohrmann Print Service, Zutphen, Netherlands, 2014.

Sultan RA, Kabir MSH, Uddin MMN, Uddin M, Mahmud ZA, Raihan SZ, Qais N. Ethnopharmacological investigation of the aerial part of Phragmites karka (Poaceae). J Basic Clin Physiol Pharmacol. 2017. 28; 283-91.

Tiggelman AM, Boers W, Linthorst C, Sala M, Chamuleau RA. Collagen synthesis by human liver (myo)fibroblasts in culture: Evidence for a regulatory role of IL-1 beta, IL-4, TGF beta and IFN gamma. J Hepatol. 1995; 23: 307-17.

Tsukada S, Parsons CJ, Rippe RA. Mechanisms of liver fibrosis. Clin Chim Acta. 2006; 364: 33-60.

van Acker SA, de Groot MJ, van den Berg DJ, Tromp MN, Donne-Op den Kelder G, van der Vijgh WJ, Bast A. A quantum chemical explanation of the antioxidant activity of flavonoids. Chem Res Toxicol. 1996; 9: 1305-12.

Zhou WC, Zhang QB, Qiao L. Pathogenesis of liver cirrhosis. World J Gastroenterol. 2014; 20: 7312-24.

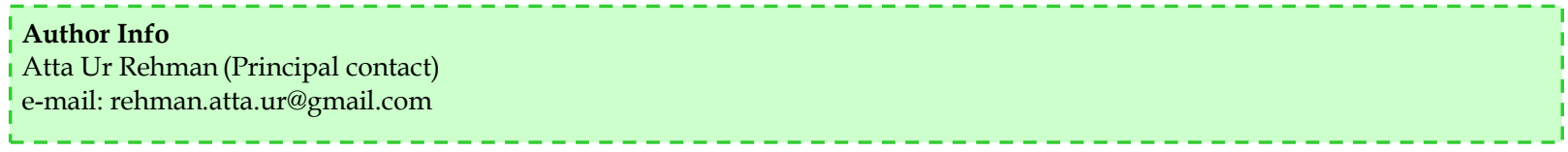

